\title{
Use of the Whatsapp application in health follow-up of people with HIV: a thematic analysis
}

\author{
Uso do aplicativo Whatsapp no acompanhamento em saúde de pessoas com HIV: uma análise temática \\ Uso de aplicación Whatsapp para seguimiento de salud de personas con VIH: un análisis temático
}

\author{
Ivana Cristina Vieira de Lima ${ }^{1}$ (C) \\ Marli Teresinha Gimeniz Galvão ${ }^{1}$ \\ Samyla Citó Pedrosa ${ }^{1}$ \\ Gilmara Holanda da Cunha ${ }^{1}$ \\ Ana Karoline Bastos Costa $^{1}$
}

1. Universidade Federal do Ceará.

Fortaleza, CE, Brasil.

\begin{abstract}
Objective: To investigate the statements of people living with HIV during a health follow-up through the WhatsApp ${ }^{\circledR}$ application. Methods: A descriptive study, using a qualitative approach, was conducted with 26 people accompanied by two specialized care services for HIV/AIDS in Fortaleza, Ceará. Data were collected from September 2016 to February 2017, with participants' statements given during the online follow-up and submitted to thematic content analysis. Results: The following categories emerged: difficulties with treatment, antiretroviral dose delayed or missed, side effects, association between antiretroviral drugs and alcohol, use of dietary supplements and medicines, emotional changes, life habits, social rights, physical symptoms, and coping with and committing to with treatment. Conclusion: Follow-up over WhatsApp ${ }^{\oplus}$ improved access to health professionals, by providing an open and immediate communication channel.
\end{abstract}

Keywords: Text Messaging; Cell Phones; Communication; Nursing Care.

\section{Resumo}

Objetivo: Analisar depoimentos de pessoas com HIV durante um acompanhamento em saúde, a partir do aplicativo WhatsApp . $^{\circledR}$ Métodos: Pesquisa descritiva, abordagem qualitativa realizada com 26 pessoas com HIV acompanhadas em dois serviços de atenção especializada em HIV/Aids de Fortaleza, Ceará. Os dados foram coletados no período de setembro de 2016 a fevereiro de 2017, por meio de depoimentos de participantes durante o acompanhamento online, analisados a partir da análise de conteúdo temática. Resultados: Emergiram as seguintes categorias: dificuldades com o tratamento medicamentoso; atraso ou perda da dose do antirretroviral; efeitos colaterais; associação entre antirretroviral e bebida alcoólica; uso de suplementos alimentares e medicamentos; alterações emocionais; hábitos de vida; direitos sociais; sintomas físicos; enfrentamento e engajamento com o tratamento. Conclusão: $\mathrm{O}$ acompanhamento em saúde a partir do Whats $A p p^{\circledast}$ promoveu a acessibilidade do paciente ao profissional de saúde, fornecendo uma via de comunicação aberta e imediata.

Palavras-chave: Mensagem de Texto; Telefones Celulares; Comunicação; Cuidados de Enfermagem.

\section{Resumen}

Objetivo: Analizar testimonios de personas con VIH durante un seguimiento en salud utilizando la aplicación WhatsApp ${ }^{\circledR}$ Métodos: Investigación descriptiva, de abordaje cualitativo, realizada con 26 personas con VIH atendidas en dos servicios de atención especializada en VIH/SIDA de Fortaleza, Ceará. Datos recolectados durante el período entre setiembre de 2016 y febrero de 2017, a través de testimonios de participantes durante el seguimiento online, estudiados mediante análisis de contenido temático. Resultados: Surgieron las siguientes categorias: dificultades con el tratamiento farmacológico; retraso o pérdida de la dosis del antirretroviral; efectos colaterales; asociación entre antirretroviral y bebidas alcohólicas; uso de suplementos alimentarios y medicamentos; alteraciones emocionales; hábitos de vida; derechos sociales; síntomas físicos; enfrentamiento y adhesión al tratamiento. Conclusión: El seguimiento en salud a partir del WhatsApp ${ }^{\circledast}$ facilitó la accesibilidad del paciente al profesional de salud, ofreciendo una vía de comunicación abierta e inmediata.

Palabras clave: Mensaje de Texto; Teléfonos Celulares; Comunicación; Atención de Enfermería.
Corresponding author:

Ivana Cristina Vieira de Lima.

E-mail: doutorandaivana@gmail.com

Submitted on $01 / 03 / 2018$.

Accepted on 02/07/2018.

DOI: 10.1590/2177-9465-EAN-2017-0429 


\section{INTRODUCTION}

The use of information and communication technologies in health care services began in the 1990s, with the expansion of social media, also known as Web 2.0 or social networks, which are defined as a set of Internet-based tools aimed to help users connect, collaborate and communicate with other people in real time. ${ }^{1}$

Social media has revolutionized not only the everyday life of people, but also the relationship between patients and professionals, ${ }^{2}$ by providing instant communication, education in health, social support, decision-making, self-care, and also by providing support to behavior changes, with good cost-effectiveness. ${ }^{3}$

In the context of HIV/AIDS, information and communication technologies have been suggested as tools aimed to improve access to health care services, through a decrease of geographical barriers and costs that involve prevention and treatment. When they are used in combination with usual care, they allow for strengthening health care services and improving quality of care, since they mitigate the difficulties experienced by people living with HIV. ${ }^{4}$

Findings have shown the positive impacts of the use of cell phones on adherence to antiretroviral therapy and viral suppression, especially in the first months, whether it is done through phone calls or messages. In spite of that, studies need to be carried out in order to assess the possibilities of use and the effectiveness of social media and smartphone apps. ${ }^{5}$

WhatsApp ${ }^{\circledR}$ Messenger is an instant messaging application run from a mobile device which allows to communicate by sharing texts and voice messages, photos, music, and videos. ${ }^{6}$ The use of this application in health care has shown satisfactory results in the integration of theory and clinical practice, in both nursing and medicine. ${ }^{8-10}$ However, the use of WhatsApp ${ }^{\circledR}$ as a tool for communication between professionals and patients and of education in health is limited to a small number of publications. ${ }^{11}$

Considering this gap, the present study was outlined to answer the following question: What topics are addressed during a follow-up provided to HIV patients over WhatsApp ${ }^{\circledR}$ ? Studies with this approach can provide grounds to a multidisciplinary team for the identification of information needs from the perspective of people involved, giving way to the expansion of tools of communication and education in health which are used every day in care services that are specialized in HIV/AIDS, with the purpose of enabling patients to overcome difficulties related to their experience with HIV.

Therefore, we analyzed the statements given by people living with HIV during a health follow-up carried out over WhatsApp ${ }^{\circledR}$.

\section{METHOD}

This is a qualitative study carried out from September 2016 to February 2017 with 26 people living with HIV who were assisted by two care services specialized in HIV/AIDS in Fortaleza, state of Ceará. Both institutions are part of the Unified Health System (SUS, as per its acronym in Portuguese) and they are reference centers that provide multidisciplinary services as well as antiretroviral drugs and follow-up examinations.

Participants were selected by means of a personal invitation while they were waiting for their medical appointment. Non-probabilistic convenience sampling was adopted with the following inclusion criteria: people living with HIV/AIDS, aged over 18, undergoing treatment for one year or less, literate, who owned a cell phone with access to the internet, who used WhatsApp ${ }^{\circledR}$, and agreed to receive messages. The exclusion criterion was having any physical, mental or visual constraint that limited the reception of messages.

Participants were first invited verbally, and then an interview was carried out in a private room within the health care service so they could fill in a semi-structured form for sociodemographic and clinical characterization. Participants were provided with information regarding the study and confidentiality of the follow-up.

After selection, subjects received individual messages every two weeks, which were sent by a nurse, from a cell phone exclusively used for this purpose, on business days and working hours, for four months. Messages were first validated by specialists ${ }^{12}$ and they addressed the following topics: introduction of follow-up, adherence to antiretroviral therapy, physical activity, social support, self-esteem, anxiety/depression, dietary habits, drugs and alcohol, and sexuality. In addition to the topics addressed, images with motivational messages were also sent. Throughout the follow-up, a nurse was available on WhatsApp ${ }^{\circledR}$ to clear doubts at any time.

An Excel spreadsheet was used to record chats between the nurse and participants. At the end of the follow-up, all messages sent by participants were gathered, read and submitted to thematic content analysis. The following steps were applied in the analysis: pre-analysis, material exploration or codification, result processing, inference, and interpretation. ${ }^{13}$

Results were presented in a chart with statements given by participants distributed over the following categories: difficulties with drug therapy, antiretroviral dose delayed or missed, antiretroviral side effects, association between antiretroviral drugs and alcohol, use of dietary supplements and medicines, emotional changes, life habits, social rights, physical symptoms, and coping with and commitment to treatment. Participants were identified by an alphanumeric code containing the letter $S$ (for statement) and the sequence number of participants (i.e. S1).

The study derived from a clinical trial named "Effects of a telephone follow-up program to promote the health of people living with HIV/AIDS", which was approved by the Research Ethics Committee of the Federal University of Ceará, under CAAE number 53297216.8.0000.5054, in compliance with the ethical principles of Resolution 466/12. 


\section{RESULTS}

All participants were men, employed (65.38\%), single $(73.07 \%)$, belonged to a religion $(65.38 \%)$, had a mean age of 28.6 years $( \pm)$, had an average time of diagnosis of 7.4 months $( \pm 6.6)$, 13 years of education in average $( \pm 3)$, a CD4 + count of $\geq 500$ cells $/ \mathrm{mm}(53.85 \%)$ and viral load of $\leq 3.000$ copies $/ \mathrm{ml}$ (76.92\%).

Chart 1 lists statements given by participants during their follow-up through WhatsApp ${ }^{\circledR}$. The following categories emerged: difficulties with drug therapy, antiretroviral dose delayed or missed, antiretroviral side effects, association between antiretroviral drugs and alcohol, use of dietary supplements and medicines, emotional changes, life habits, social rights, physical symptoms, and coping with and commitment to treatment (Chart 1).

\section{DISCUSSION}

The characterization of participants as to age and gender is in line with other Brazilian studies ${ }^{14-16}$ and with data from the 2016 Epidemiologic Report, which presented a higher incidence among men aged between 20 and 34 years old, homosexuals or bisexuals. ${ }^{17}$ These results suggest the need for infection prevention and care strategies aimed at young men.
Most participants have completed high school, similarly to what was found in other Brazilian ${ }^{14-15,18}$ and international studies. ${ }^{19-20}$ With regard to this particular aspect, people with higher level of education may have more access to information about HIV and greater chances of sticking to the treatment. ${ }^{18}$

The average time of diagnosis under one year is a critical period to increase knowledge about HIV and its treatment, ${ }^{16} \mathrm{a}$ condition that was confirmed in the analyses of statements given by the participants. There were questions about different topics related to their condition of living with the virus, especially the forms of transmission, interpretation of the viral load examination and research on its cure.

Having been tested positive for HIV can be a traumatic experience and brings concerns about the forms of transmission and the serological examination results, situations that can interfere with the social and emotional lives of individuals. ${ }^{21}$ For that reason, health professionals must be ready to provide emotional support and information to people with HIV. ${ }^{22}$

In the interactions between the nurse and participants, difficulties with the intake of prescribed antiretroviral drugs were reported, with doses being missed or delayed, as well as side effects and treatment interruption. This shows the challenges related to antiretroviral drug treatment adherence, which

Chart 1. Statements given by people living with HIV during a follow-up carried out through WhatsApp ${ }^{\circledR}$. Fortaleza, Ceará, 2017

\begin{tabular}{|c|c|}
\hline Category & Statement \\
\hline Knowledge about HIV & $\begin{array}{l}\text { Is it possible to transmit HIV by kissing? (S15) } \\
\text { What does it mean having a viral load lower from } 25 \text { thousand to } 103 \text { ? (S20) } \\
\text { If I have a complete blood count done, does it say I have HIV? (S12) } \\
\text { What about the experiment being carried out in some British universities regarding the } \\
\text { HIV cure? (S20) }\end{array}$ \\
\hline Difficulties with drug therapy & $\begin{array}{l}\text { I am going to do autohemotherapy. I don't feel good with these drugs. (S19) } \\
\text { Doctor, it's been } 3 \text { days since I've taken my medicine, it's run out and I haven't picked it } \\
\text { up yet. (S21) } \\
\text { I've been taking half a pill every day, until I get used to it. (S22) } \\
\text { I've stopped taking my medicine. (S19) }\end{array}$ \\
\hline $\begin{array}{l}\text { Antiretroviral dose delayed or } \\
\text { missed }\end{array}$ & $\begin{array}{l}\text { I haven't been taking them at prescribed hours, because I don't always sleep at the same } \\
\text { time every day; does that interfere in any way? (S9) } \\
\text { Do you know what happens when I take that pill twice a day? (S14) }\end{array}$ \\
\hline Side effects & $\begin{array}{l}\text { The first reaction was discomfort in the morning. Then I started to take it during the day } \\
\text { and I got dizzy. Now I'm taking them in the evening again, before I go to bed. (S20) } \\
\text { Is it normal to feel completely indisposed after taking the medicine? I'm having } \\
\text { headaches frequently. (S14) } \\
\text { I get a bad taste in my mouth, a knot in the throat, an urge to throw up. I lose sleep and } \\
\text { appetite. Some days I don't feel like taking them. (S19) } \\
\text { I've been feeling weak, unwell and having body aches. I think it's because of the } \\
\text { medicine. (S18) } \\
\text { I still have the runs when I take it. (S23) } \\
\text { I've been urinating more often now than before I started to take it. Is that bad? (S20) }\end{array}$ \\
\hline
\end{tabular}




\begin{tabular}{|c|c|}
\hline Category & Statement \\
\hline $\begin{array}{l}\text { Association between } \\
\text { antiretroviral drugs and alcohol }\end{array}$ & $\begin{array}{l}\text { Is it ok if I have a beer before I take my medicine? (S13) } \\
\text { Can I drink alcohol? (S23) }\end{array}$ \\
\hline $\begin{array}{l}\text { Use of dietary supplements and } \\
\text { medicines }\end{array}$ & $\begin{array}{l}\text { Can I take vitamins without any trouble? (S18) } \\
\text { I'd like to know if it's ok to use a bronchodilator without a prescription. (S14) } \\
\text { If I ever have a headache and the pain only goes away with a pill, can I take one? (S16) } \\
\text { Do you know anything I could take to help me sleep? (S14) } \\
\text { Doctor, could you tell me the name of some medication that would make me stop } \\
\text { smoking? (S20) }\end{array}$ \\
\hline Emotional changes & $\begin{array}{l}\text { I've been so scared lately. I'm feeling like when I found out about HIV. (S14) } \\
\text { I've been unwell, I'm worried about myself. (S8) } \\
\text { I just feel like sleeping, and I cry all the time. (S13) }\end{array}$ \\
\hline Life habits & $\begin{array}{l}\text { Now, instead of eating sweets and cakes, I've been eating fruit salad or the actual fruit. } \\
\text { (S14) } \\
\text { I've been working out, every two days, going to work by bicycle. (S8) } \\
\text { I have even cut down on smoking. (S3) }\end{array}$ \\
\hline Social rights & $\begin{array}{l}\text { Is the pension plan for HIV-positives a complicated issue today? (S18) } \\
\text { Am I entitled to free bus tickets? (S19) } \\
\text { Is it possible to have a declaration from the hospital so I can get the Bolsa Familia } \\
\text { allowance? (S21) }\end{array}$ \\
\hline Physical symptoms & $\begin{array}{l}\text { I've been sick all day. I got a bellyache. (S1) } \\
\text { I had a bout of fever, but I took a pill and I'm much better now. (S13). } \\
\text { My only problem is warts, which don't stop growing. (S2). } \\
\text { I think I have the fever, I'm going to take a pill and then I'm going to have some sle- } \\
\text { ep. I feel my eyes getting sore and have some pain in my shoulders and arms. (S17) } \\
\text { I just have some whitish stains over my body. (S23) }\end{array}$ \\
\hline $\begin{array}{l}\text { Coping with and commitment to } \\
\text { treatment }\end{array}$ & $\begin{array}{l}\text { [...] move on like any other person, and at each appointment, I'm happy with the results, } \\
\text { and it's a win-win situation if I carry on with the treatment. (S10) } \\
\text { I was afraid of the side effects, but I took heart and I'm going to take my medicine again } \\
\text { today. (S23) } \\
\text { Now I have medical appointments every six months. Treatment is going well and results } \\
\text { are great. (S5) } \\
\text { I got to read the tuberculosis exam result. There was nothing. Everything is ok. (S26) } \\
\text { My examination result was "undetectable". (S7) }\end{array}$ \\
\hline
\end{tabular}

represents at least $80 \%$ of the intake of pills aimed at suppressing viruses and maintenance. ${ }^{23}$

This low adherence to drug treatment is one of the main reasons for treatment failure, ${ }^{24}$ resulting in the failure of basic treatment schemes and the need to use more complex rescue treatment schemes, which are more expensive and require a higher number of pills. ${ }^{25}$ Moreover, failure to having people adhere to treatment results in personal damages such as decreased quality of life, a decrease in CD4+ cell count, viral resistance, disease progression to AIDS and death. There are also collective damages that may affect virus transmission control and which result in increased costs with treatment and hospitalizations. $^{26}$

As a result of these effects, it is essential to establish a therapeutic partnership between the client and health professionals, based on empathy, autonomy, and bonds, in such a way that clients feel comfortable to express their anguish, fears, and expectations with regard to their life with HIV. ${ }^{27-29}$ In this context, the follow-up through WhatsApp ${ }^{\circledR}$ represented the opportunity to communicate and clear doubts in real time, making it easier to manage difficulties associated with the treatment, with positive effects on treatment adherence.

Another matter that raised doubts among participants was the association between the use of the antiretroviral drug and alcohol intake. Although a low alcohol intake does not have negative effects on antiretroviral therapy adherence, it should be discouraged because of its harmful effects on quality of life and of the increased risk of hepatotoxicity. ${ }^{15,30-31}$ Therefore, professionals must address the recreational use of alcohol, advising patients not to interrupt drug treatment. ${ }^{17}$

Another doubt was related to the use of dietary supplements and other drugs, which suggests the need to inform all people 
with HIV about these issues, with the purpose of preventing treatment flaws and/or side effects related to a possible interaction with antiretroviral drugs. ${ }^{32}$

Another aspect observed among people living with HIV was the expression of emotional changes, such as fear, concern, discouragement, drowsiness and frequent crying. These complaints can be associated with a diagnosis of anxiety and/or depression, which are frequent among this group. ${ }^{33}$ This setting points to the importance for a multidisciplinary team to continuously assess the mental health of people living with HIV and to recommend strategies to control these disorders, with the use of prescribed drugs, support groups, psychological counseling, and complementary treatment ${ }^{33,34}$

A topic mentioned by participants was the search for healthy habits like having a healthy diet, doing physical activities, and reducing smoking. This is in line with a study carried out with people recently diagnosed with HIV. ${ }^{35}$ These changes in life style are important to prevent the metabolic changes caused by the body's response to HIV and/or by antiretroviral drug toxicity, which can increase the prevalence of diabetes, resistance to insulin, dyslipidemia, lipodystrophy, bone alterations, in addition to early cerebrovascular and cardiovascular diseases. ${ }^{34}$

Social rights such as disability retirement, right to free transportation and entitlement to allowances from the Bolsa Familia program also raised doubts among patients. Interest in these social benefits can be related to social vulnerability, ${ }^{14}$ a typical characteristic of the HIV epidemic that may imply in difficulties in access to health services and continuity of care. For that reason, information provided by social workers after diagnosis is essential to foster knowledge about social rights guaranteed by law.

Participants consider nurses as a source of support to report physical symptoms associated with acute conditions, which was also found in a previous study. ${ }^{19}$ This allowed for the referral to specialized emergency units and anticipation of medical appointments with an ID specialist, providing a prompter follow-up and preventing the deterioration of the clinical condition.

Communicating with nurses was also useful to share treatment adherence rates and satisfactory results of examinations, which allowed for a positive feedback of good clinical results. In the context of HIV, this partnership is crucial, since patients feel the need to be heard and get the attention of health professionals in order to cope with the disease, and in some cases, they are the only ones who patients can share their achievements with. ${ }^{35}$

\section{CONCLUSIONS}

Analysis of the participants' statements showed that followup over WhatsApp ${ }^{\circledR}$ improved access to health professionals, by providing an open and immediate communication channel that made patients feel safer to overcome their difficulties with treatment, in addition to sharing their achievements and promoting healthy habits. This study also highlighted the importance of providing information and emotional support during the first months of treatment.

The use of the WhatsApp ${ }^{\circledR}$ application has proven to be useful as a health care tool for people living with HIV, and a potential channel to clear doubts and promote treatment adherence. This study can provide grounds to broaden care provided by a multidisciplinary team in HIV-specialized services with the use of an innovative technology that is little explored in the Brazilian setting.

A limitation of this study was the absence of an analysis of patients' messages responded by nurses, which made it impossible to assess the information provided by professionals.

\section{ACKNOWLEDGMENTS}

To the National Council for Scientific and Technological Development (CNPq) for granting a PhD fellowship to the first author and for financing this study.

\section{REFERENCES}

1. Ressler PK, Glazer G. Legislative: nursing's engagement in health policy and healthcare through social media. Online $\mathrm{J}$ Issues Nurs [Internet] 2010 Oct 22; [cited 2017 Sep 25]; 16(1):11. Available from: http://www. ncbi.nlm.nih.gov/pubmed/21800931

2. George DR, Rovniak LS, Kraschnewski JL. Dangers and opportunities for social media in medicine. Clin Obstet Gynecol [Internet]. 2013 Sep; [cited 2017 Sep 21]; 56(3):453-62. Available from: http://www.ncbi.nlm. nih.gov/pubmed/23903375

3. Muessig KE, Nekkanti M, Bauermeister J, Bull S, Hightow-Weidman LB. A Systematic Review of Recent Smartphone, Internet and Web 2.0 Interventions to Address the HIV Continuum of Care. Curr HIV/AIDS Rep [Internet]. 2015 Mar; [cited 2017 Sep 25]; 12(1):173-90. Available from: http://www.ncbi.nlm.nih.gov/pubmed/25626718

4. Catalani C, Philbrick W, Fraser H, Mechael P, Israelski DM. mHealth for HIV Treatment \& Prevention: A Systematic Review of the Literature. Open AIDS J [Internet]. 2013 Aug; [cited 2017 Sep 21]; 7:17-41. Available from: http://www.ncbi.nlm.nih.gov/pubmed/24133558

5. Lima IC, Galvão MT, Alexandre Hde O, Lima FE, Araújo TL. Information and communication technologies for adherence to antiretroviral treatment in adults with HIV/AIDS. Int J Med Inform [Internet]. 2016 Aug [cited 2017 Dec 28]; 92:54-61. Available from: https://www.ncbi.nlm.nih. gov/pubmed/27318071

6. WhatsApp Inc. Sobre o WhatsApp. Nosso App. [Internet]. 2017 [cited 2017 Dec 28]. Available from: https://www.WhatsApp.com/about/

7. Willemse JJ. Undergraduate nurses reflections on Whatsapp use in improving primary health care education. Curationis [Internet]. 2015 Aug; [cited 2017 Sep 25]; 38(2):1512. Available from: http://www.ncbi. nlm.nih.gov/pubmed/26304053

8. Sidhoum N, Dast S, Abdulshakoor A, Assaf N, Herlin C, Sinna R WhatsApp: Improvement tool for surgical team communication. J Plast Reconstr Aesthet Surg [Internet]. 2016 Nov; [cited 2017 Sep 21]; 69(11):1562-3. Available from: http://www.ncbi.nlm.nih.gov/ pubmed/27341767

9. Jamal A, Temsah MH, Khan SA, Al-Eyadhy A, Koppel C, Chiang MF. Mobile Phone Use Among Medical Residents: A Cross-Sectiona Multicenter Survey in Saudi Arabia. JMIR Mhealth Uhealth [Internet] 2016 May; [cited 2017 Sep 21]; 4(2):e61. Available from: http://www. ncbi.nlm.nih.gov/pubmed/27197618

10. Petruzzi M, De Benedittis M. WhatsApp: a telemedicine platform for facilitating remote oral medicine consultation and improving clinica examinations. Oral Surg Oral Med Oral Pathol Oral Radiol [Internet] 2016 Mar; [cited 2017 Sep 25]; 121(3):248-54. Available from: http:// www.ncbi.nlm.nih.gov/pubmed/26868466 
11. Veneroni L, Ferrari A, Acerra S, Massimino M, Clerici CA. Considerations on the use of WhatsApp in physician-patient communication and relationship. Recenti Prog Med [Internet]. 2015 Jul; [cited 2017 Sep 25]; 106(7):331-6. Available from: http://www.ncbi.nlm.nih.gov/ pubmed/26228724

12. Lima ICV, Galvão MTG, Pedrosa SC, Silva CAC, Pereira MLD.Validação de mensagens telefônicas para promoção da saúde de pessoas com HIV. Acta Paul Enferm [Internet]. 2017 May/Jun; [cited 2017 Dec 28]; 30(3):227-32. Available from: http://www.scielo.br/scielo. php?script=sci_arttext\&pid=S0103-21002017000300227\&lng=en. http://dx.doi.org/10.1590/1982-019420170

13. Bardin L. Análise de conteúdo. São Paulo: Edições 70; 2011.

14. Fiuza MLT, Lopes EM, Alexandre HO, Dantas PB, Galvão MTG, Pinheiro AKB. Adherence to antiretroviral treatment: comprehensive care based on the care model for chronic conditions. Esc Anna Nery [Internet]. 2013; [cited 2017 Sep 21]; 17(4):740-8. Available from: http://www. gnresearch.org/doi/10.5935/1414-8145.20130019

15. Silva RAR, Silva RTS, Nascimento EGC, Gonçalves OP, Reis MM, Silva BCO. Clinical-epidemiological profile of hiv-positive adults attended in a hospital from Natal/RN. Rev Pesqui Cuid Fundam (Online). [Internet]. 2016 Jul; [cited 2017 Sep 25]; 8(3):4689-96. Available from: http://www. seer.unirio.br/index.php/cuidadofundamental/article/view/4294

16. Silva RAR, Nelson ARC, Duarte FHS, Prado NCC, Holanda JRR, Costa DARS. Evaluation of adherence to antiretroviral therapy for AIDS patients. Rev Pesqui Cuid Fundam (Online) [Internet]. 2017 Mar; [cited 2017 Dec 28]; 9(1):15-20. Available from: http://www.ssoar.info/ssoar/ handle/document/53583

17. Ministério da Saúde (BR). Secretaria de Vigilância em Saúde. Departamento de DST. Aids e Hepatites virais. Protocolo clínico e diretrizes terapêuticas para manejo da infecção pelo HIV em adultos. Brasília (DF): Ministério da Saúde; 2017.

18. Galvão MTG, Soares LL, Pedrosa SC, Fiuza MLT, Lemos LA. Qualidade de vida e adesão à medicação antirretroviral em pessoas com HIV. Acta Paul Enferm [Internet]. 2015 Jan/Feb; [cited 2017 Sep 21]; 28(1):48-53. Available from: http://www.scielo.br/scielo.php?script=sci arttext\&pid=S0103-21002015000100048\&lng=pt\&tlng=pt

19. Kutnick AH, Gwadz MV, Cleland CM, Leonard NR, Freeman R, Ritchie AS, et al.; BCAP Collaborative Research Team. It's a Process: Reactions to HIV Diagnosis and Engagement in HIV Care among High-Risk Heterosexuals. Front Public Health [Internet]. 2017 May; [cited 2017 Dec 28]; 5:100. Available from: https://www.ncbi.nlm.nih. gov/pubmed/28540287

20. Perazzo J, Reyes D, Webel A. A Systematic Review of Health Literacy Interventions for People Living with HIV. AIDS Behav [Internet]. 2017 Mar; [cited 2017 Dec 28]; 21(3):812-21. Available from: https://www. ncbi.nlm.nih.gov/pubmed/26864691

21. Bezabhe WM, Chalmers L, Bereznicki LR, Peterson GM. Adherence to Antiretroviral Therapy and Virologic Failure: A Meta-Analysis. Medicine (Baltimore) [Internet]. 2016 Apr; [cited 2017 Dec 28]; 95(15):e3361. Available from: https://www.ncbi.nlm.nih.gov/pubmed/27082595

22. Paschoal EP, Santo CCE, Gomes AMT, Santos Él, Oliveira DC, Pontes APM. Adherence to antiretroviral therapy and its representations for people living with HIV/AIDS. Esc Anna Nery [Internet]. 2014; [cited 2017 Sep 25];18(1):32-40. Available from: http://www.gnresearch.org/ doi/10.5935/1414-8145.20140005

23. Silva JAG, Dourado I, Brito AM, Silva CAL. Fatores associados à não adesão aos antirretrovirais em adultos com AIDS nos seis primeiros meses da terapia em Salvador, Bahia, Brasil. Cad Saúde Pública [Internet]. 2015 Jun; [cited 2017 Sep 25];31(6):1188-98. Available from: http://www.scielo.br/scielo.php?script=sci_arttext\&pid=S0102-311X2 $015000601188 \& \operatorname{lng}=\mathrm{pt \&}$ tIng $=\mathrm{pt}$
24. Hickner J. Shifting our focus to HIV as a chronic disease. J Fam Pract [Internet]. 2014 Jul; [cited 2017 Dec 28]; 63(7):355. Available from: https://www.ncbi.nlm.nih.gov/pubmed/25198207

25. Macêdo SM, Sena MCS, Miranda KCL. Consulta de enfermagem ao paciente com HIV: perspectivas e desafios sob a ótica de enfermeiros. Rev Bras Enferm [Internet]. 2013 Mar/Apr; [cited 2017 Sep 21]; 66(2):196-201. Available from: http://www.scielo.br/scielo. php?script=sci_arttext\&pid=S0034-71672013000200007\&lng=pt\&t| $\mathrm{ng}=\mathrm{pt}$

26. Silva RAR, Nelson ARC, Duarte FHS, Prado NCC, Costa RHS, Costa DARS. Limites e obstáculos na adesão à terapia antirretroviral. Rev Pesqui Cuid Fundam (Online) [Internet]. 2014 Oct/Dec; [cited 2017 Dec 28]; 6(4):1732-42. Available from: http://www.seer.unirio.br/index.php/ cuidadofundamental/article/view/3148/pdf_1309

27. Zuge SS, Paula CC, Brum CN, Ribeiro AC, Padoin SMM. Adesão ao tratamento antirretroviral para o HIV e sua inter-relação com a vulnerabilidade programática. Rev Pesqui Cuid Fundam (Online) [Internet]. 2015 Oct/Dec; [cited 2017 Sep 25]; 7(4):3406-17. Available from: http://pesquisa.bvs.br/brasil/resource/pt/bde-27220

28. Santos VF, Galvão MTG, Cunha GH, Lima ICV, Gir E. Alcohol effect on HIV-positive individuals: treatment and quality of life. Acta Paul Enferm [Internet]. $2017 \mathrm{Jan} / \mathrm{Feb}$; [cited $2017 \mathrm{Dec} 28$ ]; 30(1):94-100. Available from: http://www.scielo.br/scielo.php?script=sci_arttext\&pid=S010321002017000100094\&lng=en

29. Marshall BD, Operario D, Bryant KJ, Cook RL, Edelman EJ, Gaither JR, et al. Drinking trajectories among HIV-infected men who have sex with men: a cohort study of United States veterans. Drug Alcohol Depend [Internet]. 2015 Mar; [cited 2017 Sep 21]; 148:69-76. Available from: http://www.ncbi.nlm.nih.gov/pubmed/25596785

30. Jalloh MA, Gregory PJ, Hein D, Risoldi Cochrane Z, Rodriguez A Dietary supplement interactions with antiretrovirals: a systematic review. Int J STD AIDS. [Internet]. 2017 Jan; [cited 2017 Dec 28]; 28(1):4-15. Available from: https://www.ncbi.nlm.nih.gov/pubmed/27655839

31. Robertson K, Bayon C, Molina JM, McNamara P, Resch C, MuñozMoreno JA, et al. Screening for neurocognitive impairment, depression, and anxiety in HIV-infected patients in Western Europe and Canada. AIDS Care [Internet]. 2014; [cited 2017 Sep 25]; 26(12):1555-61. Available from: http://www.ncbi.nlm.nih.gov/pubmed/25029599

32. Gregory R, Gilles C, Aude A, Laurie L, Leïla B, Jean-Cyr Y, et al Effects of massage therapy on anxiety, depression, hyperventilation and quality of life in HIV infected patients: A randomized controlled trial. Complement Ther Med [Internet]. 2017 Jun; [cited 2017 Dec 28]; 32:109-14. Available from: https://www.ncbi.nlm.nih.gov/ pubmed/28619295

33. Alexandre HO, Galvão MTG, Lima ICV, Guedes DS, Pedrosa SC, Cunha $\mathrm{GH}$, et al. Perceptions That People Newly Diagnosed With Hiv Have On Health. Int Arch Med [Internet]. 2016 Jul; [cited 2017 Sep 21]; 9. Available from: http://imed.pub/ojs/index.php/iam/article/view/1686

34. Kramer AS, Lazzarotto AR, Sprinz E, Manfroi WC. Alterações metabólicas, terapia antirretroviral e doença cardiovascular em idosos portadores de HIV. Arq Bras Cardiol [Internet]. 2009 Nov; [cited 2017 Sep 25]; 93(5):561-8. Available from: http://www.scielo.br/scielo. php?script=sci_arttext\&pid=S0066-782X2009001100019\&lng=pt\&n $\mathrm{rm}=\mathrm{iso} \& \mathrm{t}$ lng $=\mathrm{pt}$

35. Brion J. The patient-provider relationship as experienced by a diverse sample of highly adherent HIV-infected people. J Assoc Nurses AIDS Care [Internet]. $2014 \mathrm{Mar} / \mathrm{Apr}$; [cited 2017 Sep 21]; 25(2):123-34. Available from: http://www.ncbi.nlm.nih.gov/pubmed/23809659 